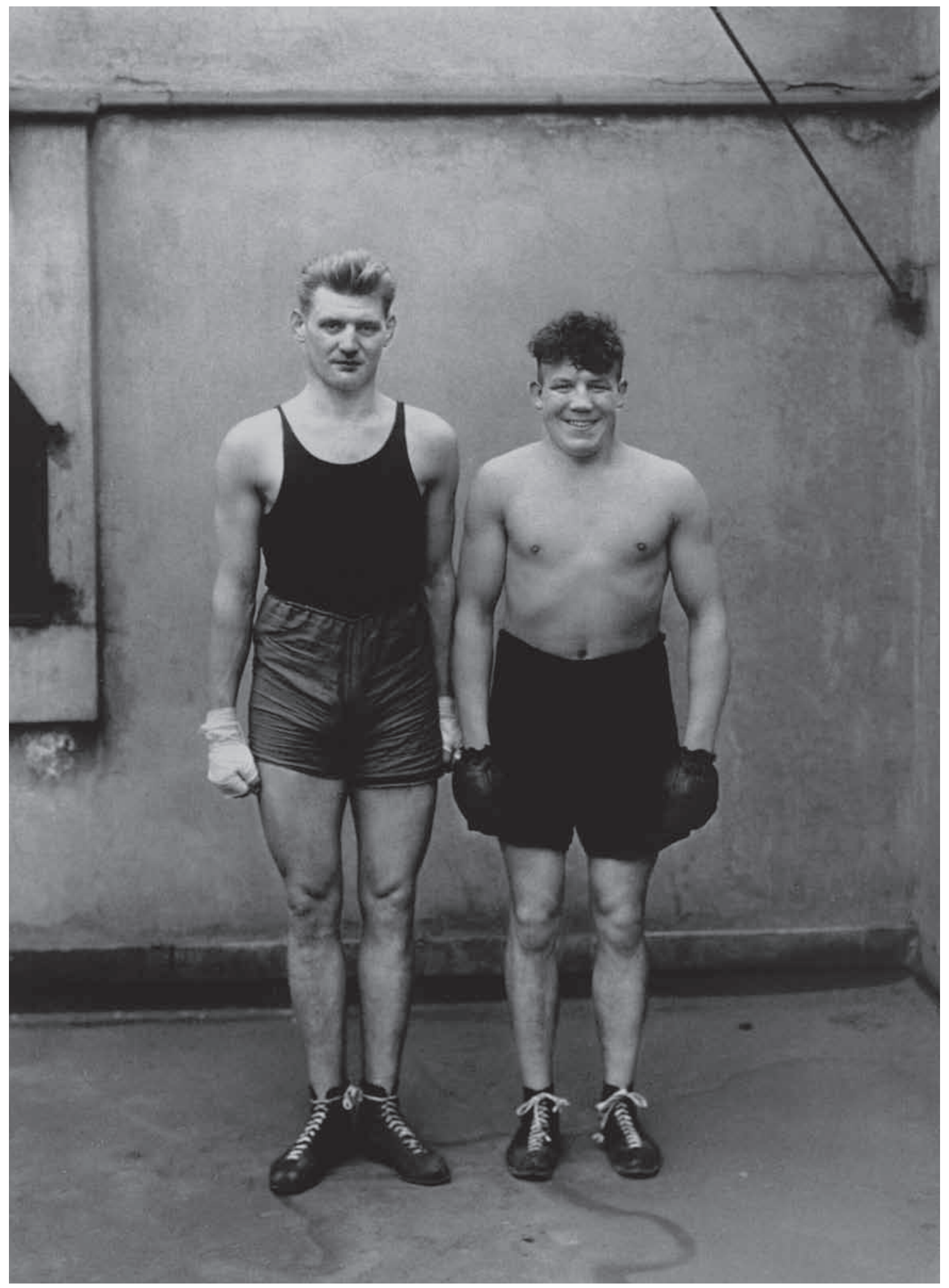




\section{Dimensões comunicacionais no conceito de escultura social de Joseph Beuys como possibilidade de tradução criativa.}

Palavras-chave:

Comunicação, Escultura Social, Joseph Beuys, Arte, Tradução.

Key-Words: Comunication, Social Sculpture, Joseph Beuys, Art, Translation.

August Sander, Boxers (Hein Heese and Paul Roderstein) Cologne, Ilustração n.13 em Antlitz der Zeit (Face of Time) impressão fotográfica, 1928.

*Universidade do Oeste de Santa Catarina (UNOESC).
O presente artigo é resultado de pesquisa de doutorado em Comunicação e Semiótica, realizada na PUC-SP, sobre o conceito de Escultura Social na obra de Joseph Beuys, com recorte em pesquisadores como Matthias Bunge e Caroline Tisdall, bem como a influência dos filósofos românticos Schiller, Goethe, Hegel e de Novalis na construção deste conceito na obra de Rudolf Steiner. O contexto da arte é abordado através de críticos de arte que analisam o trabalho artístico de Beuys, cujas características comunicacionais são apresentadas em relação a Humberto Maturana e Francisco Varella e à crítica da comunicação. Finalmente, o artigo aborda a possibilidade de tradução criativa (Walter Benjamin, Georg Steiner e Haroldo de Campos) deste conceito de Joseph Beuys.

This article is the result of $\mathrm{PhD}$ research in Communication and Semiotics at PUC (SP), with the cutout on the concept of Social Sculpture in the work of Joseph Beuys' researchers such as Matthias Bunge and Caroline Tisdall as well as about the influence of Romantic philosophers as Schiller, Goethe, Hegel and Novalis in the construction of this concept in the work of Rudolf Steiner. The art context is discussed throughout art critics who analyze Beuys artwork, which communicational characteristics are presented in relation to Humberto Maturana and Francisco Varella and to the communication critic theory. Finally, the article presents the possibility of creative translation (Walter Benjamin, Georg Steiner and Haroldo de Campos) of this concept of Joseph Beuys. 
O artista alemão Joseph Beuys (1921-1986) provoca com sua arte, até os dias atuais, reflexões acerca da própria arte, da pedagogia, da comunicação, da antroposofia, bem como acerca da interdisciplinaridade entre arte e vida. Iniciaremos apresentando a visão de Mathias Bunge ${ }^{1}$, que afirma que toda a produção de Joseph Beuys pode ser compreendida como Escultura Social, desde aquarelas, desenhos, performances, instalações, vitrines, múltiplos, até as imagens invisíveis. Esse autor descreve o que compreendemos nesta pesquisa como "processo comunicacional", ou seja, o fato de Beuys trabalhar as "imagens" para fazer as pessoas refletirem a partir de sua arte, quando diz:

De modo absolutamente decidido, ele se ateve ao meio não verbal da imagem (imago), pois esta produziria, por meio da intuição sensível, um efeito imediato sobre a consciência intelectual e seria, por conseguinte, especialmente apropriada a provocar irritações e pôr em marcha movimentos do pensar. Esculturas, ações e instalações espaciais também se afiguram como "imagens" a Beuys².

A citação acima nos faz estabelecer uma conexão com o espaço digital, no sentido em que o som da fala, som do ambiente, os materiais e os textos configuram-se como imagens, dando significados à imaginação proposta por Beuys, não estabelecendo apenas as imagens literalmente aos seus significados, mas indo além, envolvendo o espectador em um tipo de produção digital como a hipermídia. ${ }^{3}$. Além disso, quando Beuys utiliza materiais inusitados, estranhos, em suas obras, isso promove um conflito mental que nos faz buscar um significado, promover o raciocínio e a ação para uma possível compreensão. Realizamos também uma conexão em Rudolf Steiner ${ }^{4}$, a partir dessa fala de Bunge, quando aquele resume que para o indivíduo poder ver e vivenciar o espiritual, precisa "tornar as imagens espiritualmente transparentes por meio de sua constante atuação nelas. (...) Finalmente a pessoa não as verá mais - apenas as sentirá vivas na alma, mas através delas perceberá os seres da realidade suprassensível”’ Acreditamos que Joseph Beuys encontrou na antroposofia sua forma de perceber e produzir arte, buscando, da mesma forma que a Ciência Ocul$\operatorname{ta}^{6}$ de Steiner, a transformação, a "transmutabilidade" ${ }^{7}$ no mundo físico e mental dos homens. O conceito de imagem (representações gráficas, fotográficas, holográficas, artísticas da realidade ou imaginárias), segundo Bunge propõe, pode acontecer não simples e literalmente associado ao objeto - linhas, cores, formas estabelecidas do que se vê -, mas também

MAGDA SALETE VICINI

Dimensões

comunicacionais no

conceito de escultura

social de Joseph Beuys

como possibilidade de

tradução criativa.

1. Matthias Bunge (1956) foi professor de História da Arte na Universidade Católica de Wichstätt, e atualmente ensina na Escola Antroposófica Waldorf, em Walhausen, e na Universidade Livre de Manheim.

2. BUNGE, Matthias et al. Wer Nicht Denken Will Fliegt Raus - Joseph Beuys Postkarten. Heidelberg: Editon Braus, 1998. p. 31. Traducão de Peter Naumann.

3. Como pesquisamos em nosso mestrado, no qual se salienta essa proposta hipermidiática. Cf. VICINI, Magda. A arte de Joseph Beuys: pedagogia e hipermídia. São Paulo: Ed. Mackenzie, 2006.

4. Cf. STEINER, Rudolf. 0 limiar do mundo espiritual: considerações aforísticas. São Paulo: Antroposófica, 1994. Rudolf Steiner (1861-

1925), pedagogo austríaco que criou a "Antropologia Antroposófica", ou seja, a análise bio-psico-social do homem sob o enfoque de seu relacionamento espiritual com o Cosmo e suas forças criativas. Ver, para uma introdução, STEINER, Rudolf. A arte da educação I. São

Paulo: Editora

Antroposófica, 1988.

5. STEINER, Rudolf. Op. cit., 1994, p. 76. 
a partir de textos escritos e ambientes, como instalações, ações artísticas, performances, sons e diálogos executados por Joseph Beuys, imagens que

\section{Ciência Oculta para Steiner: "A Ciência Oculta deseja emancipar o método e a atitude investigativa das Ciências Naturais - os quais, em sua esfera, se atêm ao contexto e ao decorrer dos fatos sensórios \\ (...). Ela quer falar sobre o não sensível do mesmo modo como as Ciências Naturais falam do sensível". In: STEINER, Rudolf. A ciência oculta: esboço de uma cosmovisão supra- sensorial. São Paulo: Editora Antroposófica, 2001, p. 33.}

7. STEINER, Rudolf. Op. cit., 1994, p. 52.
8. BUNGE, Matthias. Op.cit., p. 31.

9. Cf. VICINI, Magda. Op. cit.

10. BUNGE, Matthias. Op. cit., p. 32. Essa citação consta na pesquisa de mestrado, publicada em 2006, e nos incita a repeti-la agora pela busca de Beuys em comunicar suas ideias em toda sua produção artística. se revelam no pensamento. Beuys pretendia ir além da visibilidade do mundo e das coisas, conforme Bunge, "pois formas superiores do pensamento são a intuição e as (inspirações) mediações, o conceito de imagem. Pois - imaginação - significa: a imagem, imago (...) O fato de o pensamento poder se tornar tão imagístico, esse fato precisa ser finalmente discu-

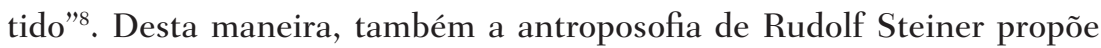
que a espiritualidade promove imagens como pensamentos e presença de seres suprassensíveis na alma de uma pessoa, como realidade suprassensível, como apresentamos a seguir.

A metodologia ${ }^{9}$ adotada pelo artista Beuys, na produção de suas obras nos leva a esta pesquisa sobre a tradutibilidade do conceito de Escultura Social. Ainda Bunge nos fornece o retrato que segue:

No terreno da arte, eis Beuys, "só devem ser criadas imagens misteriosas, de modo que todos os pontos de vista do homem sejam solicitados: o intelecto, que opera em conformidade com um esquema analítico, os sentidos, a força do sentimento..." Vários receptores que não querem perceber a unidade dos três componentes enfrentam as maiores dificuldades na tríade que consiste em (1) apresentar obras de arte enigmáticas que (2) se baseiam em uma concepção de ideias (= Teoria Escultórica) e (3) têm uma intenção decidida, mas genuinamente política (= Escultura Social). Beuys tematizou essa problemática em uma conversa que foi gravada em janeiro de 1985 para a televisão. À pergunta dos jornalistas por que tão poucas pessoas compreenderiam o seu pensamento e o seu conceito ampliado de arte, ele respondeu com a seguinte reflexão: "a minha arte realmente formula algumas exigências. E essas exigências não podem, na minha opinião, ser atingidas rapidamente pelo caminho normal do pensamento, mas devemos ter uma tranquilidade e atitude meditativa diante da coisa. Devemos, por assim dizer, saber ver ideias! E isso é difícil para as pessoas. As pessoas dizem sempre: "Onde isso já existiu, senhor Beuys?" Eu digo: se isso já tivesse existido alguma vez, eu não necessitaria falar disso. Falo sobre uma coisa que nunca existiu, e isso é difícil para as pessoas, apreender as ideias e dizer: "Uma figura inteiramente invisível, como a escultura social, deve tornar-se realidade algum dia!" ${ }^{10}$.

A proposta beuysiana objetiva a concentração de sentidos para a compreensão, procurando uma complexidade de sensações, ou seja, uma estética hipersensitiva e, proporcionando para aquele que busca sua obra, 
experiência similar a uma produção digital hipermidiática ${ }^{11}$, ou ainda, em nossa proposta, a uma tradução outra na arte. Joseph Beuys, em sua vida e sua obra, antecedeu não apenas o que poderíamos chamar de multiestética, pela diversidade de propostas, intervenções e linguagens que utilizou, mas ampliou o significado mesmo de comunicação ${ }^{12}$ que fundamenta toda a sua produção artística. Nossa análise para uma posterior tradução não pode excluir que o processo criativo de Joseph Beuys possuía uma metodologia clara quando aos objetivos que buscava alcançar, como vimos na citação de Bunge.

O contato com as obras desse artista, sua proposta comunicativa, nos faz especular sobre a possibilidade de que ele não buscava uma compreensão imediata de suas obras, mas desejava que as pessoas se sentissem integrantes de suas propostas artísticas no decorrer de suas vidas, construindo relações com seu mundo individual e coletivo, compreendendo sociedade, indivíduos, política, arte, filosofia, educação etc. Como Bunge comenta, uma percepção a partir dos sentidos que as obras provocariam. As obras de Joseph Beuys querem provocar uma comunicação - que faz parte do sentido e promove uma imagem - como arte invisível, que toca àqueles que presenciam sua obra e mesmo nós, que as visualizamos em imagens, descrições e, algumas vezes, na sonorização e silêncio que elas transmitem. A comunicação nas mídias promove um resultado esperado a partir da construção da fala, do texto ou da imagem para determinado fim; a comunicação na arte valoriza todos os elementos que constroem a obra para se chegar a um possível resultado. Assim, de qualquer forma, a proposta beuysiana nos faz pensar o sentido de comunicação, como nos diz Bunge ao pensar sobre os cartões postais produzidos por Beuys como forma de comunicar-se pela arte.

Joseph Beuys instrumentalizou o cartão postal do artista conscientemente como meio para fazer publicidade por um conceito antropológico de arte como Escultura Social. Assim o cartão postal do artista é menos uma obra de arte autônoma em formato pequeno no sentido tradicional desse termo, mas, muito pelo contrário, um meio para um fim. Em Beuys ele aparece como um veículo apropriado para a difusão de ideias, pois torna públicas as ideias do artista, multiplicadas. Com isso, ela é parte da Arte Multiplicada, apreciada por Beuys ${ }^{13}$.
MAGDA SALETE VICINI

Dimensões

comunicacionais no

conceito de escultura

social de Joseph Beuys

como possibilidade de

tradução criativa.

11. Proposta inserida em VICINI, Magda. Op. cit.

12. Comunicação na obra de Joseph Beuys adquire esse significado pelo fato de buscar incansavelmente uma forma, um meio de fazer arte que o aproximasse de um público, enviando uma mensagem a partir das linguagens do desenho, escultura, objetos (múltiplos), performances, instalações, ações, cartões postais (múltiplos) e aquarelas, propondo a teoria escultórica e o conceito de Escultura Social como mensagem nessas linguagens. Vejamos a afirmação do Dr. Helmut Gold Diretor do Museu dos Correios e de Comunicação Frankfurt:

“Justamente para Beuys, a comunicação foi um tema importante, se não o tema central da sua arte. Com vistas a esse tema, ele recorria aos meios e às possibilidades mais distintas e imagináveis da multiplicação.

0 cartão postal, de aparência supostamente singela, desempenha aqui também - e justamente - uma função importante.

Beuys usou-o, como meio, propositalmente e com grande cuidado". 


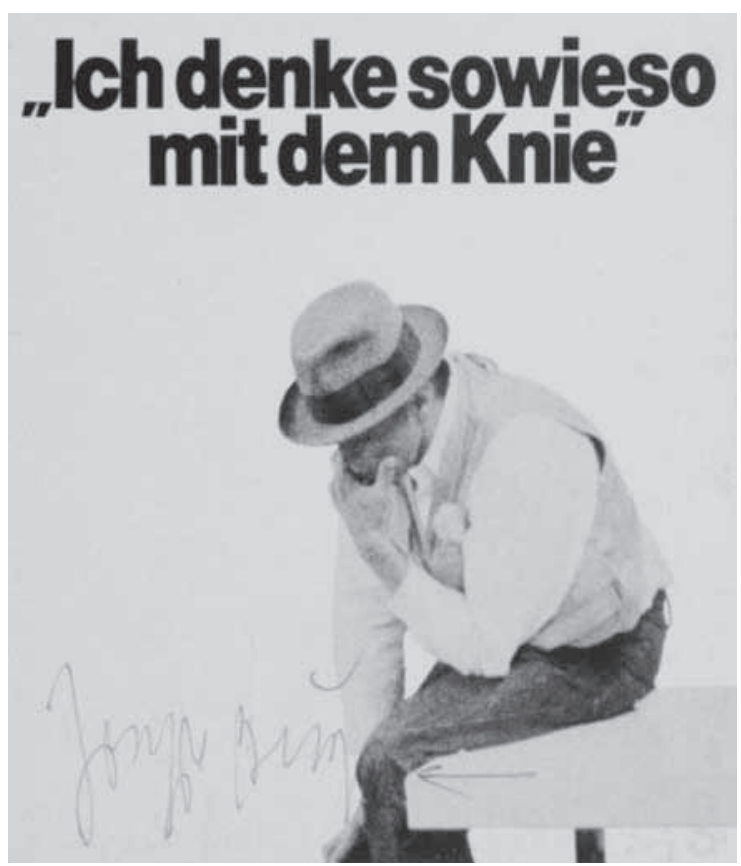

Ich denke sowieso mit dem Knie - Penso também com os joelhos -

Apud BUNGE, Matthias. Op. cit., p. 16. Ver também D'AVOSSA, Antonio; HARLAN, Volker; RAPPMANN, Rainer. A revolução somos nós Joseph Beuys. São Paulo:

Ed. Sesc, 2010, p. 14; BORER, Alain. Joseph Beuys. São Paulo: Cosac \& Naify, 2001, p. 14; DURINI, Lucrezia de Domizio (org.) Joseph Beuys: the image of humanity. Trenteo: Silvana Editoriale/Museo di Arte Moderna e Contemporanea di Trento e Rovereto, 2001, p. 24; e KUONI, Carin. Joseph Beuys in america. Nova lorque: Four Walls Eight Windows, 1993.

13. BUNGE, Matthias. Op. cit., p. 30.
Beuys procura criar passagens com o público, utilizando, para isso, diversas linguagens, meios que produzam pensamentos, atitudes, reações, numa forma ávida de comunicar-se a qualquer custo. Esse desejo de comunicar-se em Beuys nos faz imaginar o que ele poderia fazer com a internet em nosso tempo atual. A emissão e recepção de cartões pelo mundo, bem como as imagens dos cartões em fotos, frases, materiais, provocariam tal efeito pretendido? No decorrer de nosso estudo das obras de Joseph Beuys, esse aspecto vai tomando proporções cada vez maiores. $\mathrm{Na}$ sistematização de seus conceitos, na forma que escolheu para expressar-se com o mundo, fazendo uso de seus estudos de ciências naturais ${ }^{14} \mathrm{e}$ de medicina ${ }^{15}$, pois pretendia curar a humanidade ${ }^{16}$, torna-se importante colocar-se como um "verdadeiro professor de vida, Lebenslehrer", na citação de Borer ${ }^{17}$. Para este a opção pela arte tem relação direta com seus aprendizados de ciências naturais, como Beuys comenta em entrevista a Simmen e Bastian ${ }^{18}$. Na entrevista, ele fala que sua definição de vida seria a arte, pois esta provoca as pessoas, e isto não seria possível em um laboratório. 
Pudemos visualizar também nos documentários expostos na exposição "Joseph Beuys - a revolução somos nós" ${ }^{19}$. Os diversos encontros deste artista com pensadores e artistas de vanguarda, como Max Bense, Lama Sogyal e Andy Warhol. A visão de vanguarda de Beuys, além de explorar a história da humanidade e sua própria história, incluía realizações de experimentos com as alternativas tecnológicas da época, tendo a televisão, o cinema, a música e a fotografia, como meios expressivos. Para D’Avossa:

O próprio uso do meio televisivo sugere que a prática incentivada por Beuys subvertia as regras estáticas das vanguardas. Para superá-las, ele usava um meio humano; mas também se servia do que era, até ali, o mais avançado meio tecnológico de comunicação entre os homens. (...) a escultura social, da qual se declara intérprete, ganha forma e corpo, e se instala na mídia como ideia superior a qualquer linguagem midiática, para afirmar um conceito de arte totalmente relacionado com o homem ${ }^{20}$.

O tipo de produção e provocação que Beuys apontava em sua arte revela a produção da comunicação nas mídias, quando o emissor está em contato contínuo com seu receptor a partir das possibilidades tecnológicas que este manuseia, vê e habita em seu cotidiano. Mas com o diferencial, de buscar uma comunicação voltada para o olhar interno do homem, na busca de ampliação da percepção e transformação de atitude. Percebemos esse sentido de imersão, profundidade e espiritualidade proposto por Beuys na vivência estética imersiva da obra Plight (1985), exposta dois meses antes de sua morte e configurada em uma sala com rolos de feltro, um piano e um termômetro. Segundo Bunge

Beuys pretende remeter àquele limite "no qual tudo se movimenta na direção de um ponto crítico. Além desse ponto, tudo se altera, transmuda, e o significado genérico da arte reside provavelmente em uma transformação integral, radical do homem, principiando pela sua consciência de si mesmo. Pela configuração desse espaço por meio de determinados materiais e objetos, todos os sentidos do receptor não são apenas estimulados, mas literalmente reativados, de modo que o passo da percepção sensorial para a percepção do sentido (ver ideias) não fica difícil. (...) No lugar da costumeira indiferença e do desinteresse, ocorre forçosamente - intencionada e iniciada pelo artista - uma interação interpessoal: a Escultura Social é vivenciável nos modos sensível e intelectual ${ }^{21}$.
MAGDA SALETE VICINI

Dimensões

comunicacionais no

conceito de escultura

social de Joseph Beuys

como possibilidade de

tradução criativa.

14. Cf. ADRIANI,Gotz; KONNERTZ, Winfried; THOMAS, Karin. Joseph Beuys: life and works. New York: Barrons Educational Series, Inc., 1979.

15. Beuys sonhava em estudar medicina, segundo BORER, Alain.

Op. cit., p. 34.

16. Segundo Borer (Idem, ibidem) e segundo Caroline Tisdall (Joseph

Beuys: we go this way. London: Violette Editions, 1998, p. 30) quando ela refere-se à "ferida da sociedade, particularmente as tendências que causaram as atrocidades do Nazismo".

17. BORER, Alain. Op. cit., p. 34.

18. BASTIAN, Heiner \& SIMMEN, Jeannot. ZEICHNUNGEN Tekeningen drawings - Joseph Beuys. Ausstellung und Katalog. München: PrestelVerlag, 1979.

19. SESC São Paulo setembro a novembro de 2010 .

20. D'AVOSSA, Antonio. Op. cit., p. 14. 
Imaginamos ${ }^{22}$ entrar nesse ambiente da obra Plight, totalmente isolado acusticamente pelos feltros, no qual ouvimos inclusive nossos pensa-

21. BUNGE, Matthias. Op. cit., p. 32.

22. Escrevemos este texto após visualizarmos as várias imagens expostas no youtube sobre esta obra. Video Joseph Beuys Plight 1986: State of the Art Episode 3. Disponível em: 〈http://www.youtube.com/ watch?v=lokboM4wqlw;; Joseph Beuys, Plight, 1985. Centre Georges Pompidou Parigi. Postado por Eleonora Tarantino. Disponível em: 〈http://www.youtube.com/ watch?v=Enjjm8KUS2Y .

Acesso em: janeiro de 2010. Também a partir das imagens dos livros citados ao longo deste artigo e em nossa bibliografia complementar.

23. GOLDBERG, RoseLee. A arte da performance: do futurismo ao presente. São Paulo: Ed. Martins Fontes, 2006, p. 141. mentos, e a estranheza que a arte pode provocar ao vermos tantos rolos de feltro empilhados na proposta do artista, sem termos para onde nos esconder, a não ser embaixo do piano que também nos remete à arte da música, mas que está fechado, impossível de ser tocado. Só podemos ouvir nossos pensamentos e as imagens que a mente pode gerar, pois tudo é cinza, e só nos resta o piano, o quadro negro e o termômetro para diferenciar do espaço cinza. O que será que ele queria medir? A temperatura de quê? Do calor do feltro, das pessoas que entram ou a sua própria temperatura quando da ideia de construir esta instalação? Traduzimos como um isolamento. O piano sozinho, sem alguém para tocar; o termômetro e o quadro sem nada escrito. Ao passar da sala de entrada para outra sala onde nada existe, a não ser os feltros dispostos ao redor de nossa passagem, o quê pensar? Imaginar uma música que não existe, pois nem outro piano está instalado lá. E a luz que não quer esconder nada, que deixa tudo muito visível: o que está invisível aqui? A proposta de Beuys era trabalhar com o que não está visível e, ao mesmo tempo, realizar links entre os objetos que ele próprio instalou nos lugares determinados. Deixar-se levar pelos pensamentos que surgem a partir do que vemos e sentimos. Viver uma experiência estética acreditamos ser o início de tudo: navegar no espaço/ tempo de Joseph Beuys. Encontrar o invisível no visível, criar imagens e pensamentos.

Para compreendermos o conceito de Escultura Social, buscamos também o contexto artístico e crítico sobre a arte de Beuys, mas os autores em sua maioria, não se aproximam do conceito de Escultura Social em nenhum momento de seus relatos conceituais e críticos. Vimos que eles citam principalmente o aspecto xamã, a essência social e política, a ação, a performance e a tendência multimidiática em suas obras. Somente voltamos a encontrar uma referência à Escultura Social de Beuys em Goldberg, no que ela intitula "Arte Viva: 1933-1970":

Sua ideia de "escultura social", que consistia em longas discussões com grandes grupos de pessoas em contextos variados, era basicamente um meio de ampliar a definição de arte, fazendo-a extrapolar a característica de atividade especializada. Realizada por artistas, a "escultura social" mobilizaria, em cada indivíduo, sua criatividade latente, e terminaria por moldar a sociedade do futuro ${ }^{23}$. 
Vemos que o sentido de Escultura Social dado por Goldberg se assemelha ao significado que encontramos em Tisdall e Borer ${ }^{24}$. Esses dois últimos autores, relatam em seus livros todas as características espirituais, pedagógicas, políticas e sociais de Joseph Beuys, mas não as relacionam com o conceito de Escultura Social, como o faz Bunge.

Pesquisadores, professores e críticos de arte como Paul Wood, Michael Rush e RoseLee Goldberg, situam Joseph Beuys dentro dos amplos parâmetros da arte conceitual e da arte povera, ligando sua produção com os antecedentes da videoarte, da performance, do happenning, das instalações multimídia e da arte postal, por exemplo. As referências à arte conceitual recaem principalmente ao Grupo Fluxus, Joseph Beuys e Joseph Kosuth, entre outros. Já a curadora Lucrezia Durini, acha pouco considerar a arte de Beuys como minimalista, povera, conceitual ou arte da performance, porque ele próprio se colocou por inteiro em sua arte, e "isso significa muito mais do que unidade entre vida e arte: (...) Beuys tem a intenção de ressaltar o poder antropológico da arte”25.

Já David Sylvester (1924-2001), crítico e curador inglês, escreveu uma resenha da exposição realizada em 1999 no Dia Center for the Arts, em New York. Sylvester relaciona a sensação de ver a obra de Beuys com quando "preciso tomar um remédio que irá me fazer bem: sinto que não devo deixar de tomá-lo, mas não anseio por fazê-lo" ${ }^{26}$. Esse temor, diz o crítico, se daria em função da espécie de evangelização de seus admiradores, pois era preciso reagir positivamente às suas obras, também devido ao fato lendário de seu acidente.

Analisando o contexto da arte, a crítica especializada procura não se envolver com o conceito de Escultura Social de Joseph Beuys. Em nossa compreensão, a Escultura Social de Joseph Beuys trata da essência do ser humano e sua capacidade de transformar, a partir de posicionamentos, atitudes, pensamentos e diálogos, abrangendo o ser/estar no mundo com suas implicações culturais, políticas e filosóficas, nas quais a arte é o meio de ampliar o sentido da vida. Essa arte pode utilizar os diversos meios e linguagens para se fazer viva: promovendo o pensamento/imagem em palavras/imagens ou é a palavra/imagem que pode ser a grande propulsora de pensamentos/imagens? Para a curadora e amiga de Joseph Beuys Lucrezia Durini, essas palavras de Beuys têm o significado de sua Escultura Social, que ela denomina Living Sculpture e Plastica Sociale:
MAGDA SALETE VICINI

Dimensões

comunicacionais no

conceito de escultura

social de Joseph Beuys

como possibilidade de

tradução criativa.

24. Caroline Tisdall lapud KUONI, Carin. Op. cit., p. 9) propõe que Escultura Social não possa ser associada à performance que o artista executa quando este realiza ações de diálogo com o público. Alain Borer (op. cit., p. 14), que se aproxima do conceito de Tisdall, não utiliza a terminologia Escultura

Social, mas apenas escultura, definindo como tal a forma de Beuys utilizar sua voz, sua fala como escultura.

25. DURINI, Lucrezia de Domizio (org.). Op. cit., p. 233.

26. SYLVESTER, David. Sobre arte moderna. São Paulo: Cosac \& Naify, 2006, p. 574. 
Word - esse poder para criar sons vocais para expressar nossas ideias e transmiti-las aos nossos semelhantes com todas as modificações é o atributo mais sublime do nosso organismo, e é o que mais nos distingue de outros seres vivos. (...) Para Beuys, a palavra era seu pão de cada dia. Através da palavra, ele expressa toda sua herança de sentimentos. A construção de um futuro provável, que lembrou o homem a ser fiel a si mesmo acontece com as relações de intercomunicação, silêncio, escuta e sabedoria expressiva natural ${ }^{27}$.

27. DURINI, Lucrezia de Domizio. Op. cit.,, p. 24.

28. KUONI, 1993, Op. cit., p.19.

29. Cf. BORER, Alain. Op. cit.; e TISDALL, Caroline. Op. cit., 1998 e Joseph Beuys: coyote. London, England: Thames \& Hudson, 2008.
Compreendemos que a Escultura Social em Joseph Beuys pretende provocar verbos (ação) - seja do próprio artista, seja de seu público -, promovendo a comunicação/intercomunicação em suas mais diversas formas de expressão, seja em imagem, fala, palavra, objeto, cartão, cartaz, desenho, instalação ou escultura. Para Beuys, Escultura Social e

\begin{abstract}
Meus objetos devem ser como estimulantes de transformações sobre a ideia de escultura, ou da arte em geral. Devem provocar pensamentos sobre o que pode ser escultura e como o conceito de escultura pode se estender para materiais invisíveis utilizados por todos. FORMAS DE PENSAMENTO - como nós moldamos nossos pensamentos ou FORMA DAS FALAS - como nós formamos nossos pensamentos em palavras ou ESCULTURA SOCIAL - como nós moldamos e formamos o mundo no qual nós vivemos: ESCULTURA COMO UM PROCESSO EVOLUCIONÁRIO, TODOS SÃO ARTISTAS. Eis o porquê minha escultura não seja fixa ou acabada. Processos contínuos: reações químicas, fermentações, mudanças de cores, apodrecimento, surgimento. Tudo está em estado de mudança. ${ }^{28}$
\end{abstract}

Nesse texto, Beuys define sua escultura tanto como produção de objetos, de ideias da arte em geral, de pensamentos e falas invisíveis, o que nos aproxima da visão de Bunge, na qual o conceito de Escultura Social estaria implícito em toda sua produção artística, uma vez que sua arte ampliada - arte antropológica - precisaria de todos os meios possíveis para fazer os indivíduos pensarem. Já nas análises de Borer e Tisdall ${ }^{29}$, é na ação da fala ou na conferência que estaria melhor identificada a Escultura Social. Nesse caminho, compreendemos que a Escultura Social, em sua amplitude, promove o pensamento/imagem - fala/imagem, desenvolvendo temas que mostram os problemas de toda a sociedade, de todo ser vivo, como desenvolve tanto na obra Energy plan... (1974) ${ }^{30}$ - em que discute a história, a sociedade, a política e a filosofia - como nas outras formas de expressão que utilizou. Podemos indicar a partir dessa reflexão, que nossa 
tradução pode encontrar um símbolo que represente a sociedade na qual estamos inseridos.

Nos aprofundamos nessas concepções sobre Escultura Social e comunicação na obra de Joseph Beuys ao analisarmos algumas de suas produções: Energy plan for the western man - directional forces (1974-1977) e Energy plan for a western man - I like America and America likes me - Coyote (1974). Os Múltiplos Intuition (1968) e os cartões-postais: Wer nicht denken will, Fliegt Raus. sich selbst (1977) e Ich denken mit knie Sowieso (1977), e os desenhos Pietá (1948) e ? (1958). Desde seus desenhos, até as primeiras obras citadas, acreditamos que o próprio Beuys define-se em toda a sua obra a partir das citações abaixo:

O artista social deverá ocupar, mais do que qualquer outra pessoa atuante, um patamar acima do sentimento naquele campo pleno da consciência, no qual caminhos do raciocínio em passos lógicos deverão ser percorridos sempre de novo sob um respectivo regime de controle claro, para encontrar o conceito correto, para fazer dele já no pensamento uma realidade espiritual e traduzi-lo então no ato ${ }^{31}$.

Para mim, é a ideia de mundo que produz imagens. É a chave do sinal para todas as formas de moldagem e organização. Quando eu falo com uma linguagem teórica, eu tento induzir os impulsos deste poder, o poder de compreensão total de linguagem que, para mim, é a compreensão espiritual de evolução ${ }^{32}$.

Para Beuys, a evolução como transformação do ser humano racional para um ser humano mais intuitivo e espiritual passaria por uma compreensão total desse ser, que pode ser promovida pela inteligência e pela sensibilidade despertas na consciência das pessoas: imagens que são palavras, materiais, textos, sons e pensamentos. Essa definição de Beuys nos remete a uma proposta de Maturana e Varella, quando apresentam o domínio da linguagem como essência para a consciência humana, através de uma estrutura que estabelece uma espécie de mapa do conhecimento ou como o título do livro revela: A árvore do conhecimento ${ }^{33}$. Notamos que, para esses autores, há uma necessidade de compreensão do conhecimento humano desde o organismo microcelular até os processos culturais de relações humanas, para que realmente tenhamos consciência da vida, do convívio humano e das relações de comunicação entre esses. Realizando uma comparação com Beuys, trata-se de elementos internos e externos a serem compreendidos no processo de comunicação e formação cultural
MAGDA SALETE VICINI

Dimensões

comunicacionais no

conceito de escultura

social de Joseph Beuys

como possibilidade de

tradução criativa.

30. Energy plan for the western man: Para Tisdall e em Kuoni (Op. cit. 1993), o conceito de Escultura Social se afirma na obra Energy plan... quando Beuys defende a criatividade individual de todo ser humano, pretendendo moldar a sociedade para o futuro, seguindo a definição "das pessoas, pelas pessoas e para as pessoas" mas com uma nova ênfase sobre o 'de/pela//para' com um processo criativo". TISDALL, Caroline. Op. cit., 2008, p. 8 .

Ilustração 2

Pietá, Joseph Beuys, 1948.

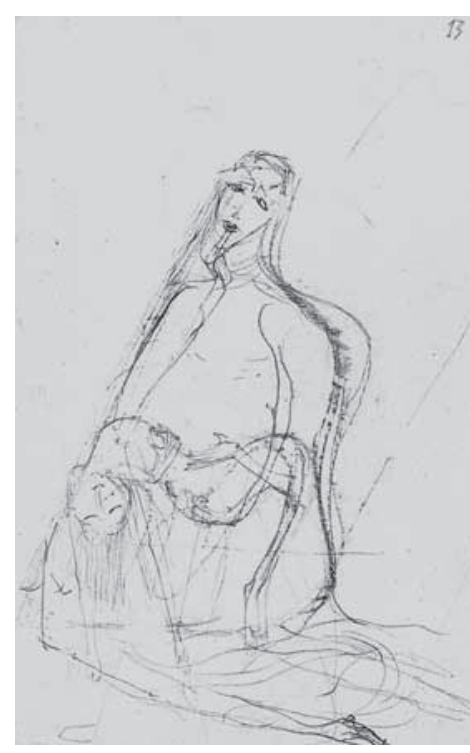


ARS humana - processos visíveis e invisíveis. Se, para Beuys, a linguagem é esano 11 piritual, incluindo forças visíveis e invisíveis, sendo promotora de intera-

n. 22 ções e transformações, esses autores, levando em consideração as diversas formas de interações comunicativas de homens e animais, afirmam que

\footnotetext{
31. BUNGE, Matthias et al. Wer nicht denken will fliegt raus - Joseph Beuys postkarten. Heidelberg: Editon Braus, 1993, p. 36. Tradução de Peter Naumann.
}

32. TISDALL, Caroline. Op. cit., 2008, p. 9.

33. MATURANA, Humberto R. \& VARELLA, Francisco G. A árvore do conhecimento: as bases biológicas do entendimento humano. São Paulo: Editorial Psy II, 1995.

34. Idem, p. 233.

35. Idem, p. 252.

36. BASTIAN, Heiner \& SIMMEN, Jeannot. Op. cit., 1979, p. 98.

37. Cf. D’Avossa, Antonio. Op. cit.

38. ADRIANI,Gotz; KONNERTZ, Winfried; THOMAS, Karin. Op. cit., 1979. o domínio linguístico do homem é muito mais abrangente e envolve muito mais aspectos de sua vida do que ocorre com qualquer animal. (...) a característica-chave da linguagem, que modifica de modo tão radical os domínios comportamentais humanos, possibilitando novos fenômenos como a reflexão e a consciência. (...) a linguagem permite a quem opera nela "descrever-se a si mesmo" e às suas circunstâncias ${ }^{34}$.

Entendemos que, para esses autores, a linguagem, como poder de comunicação, possibilita a reflexão sobre si mesmo, como também pretendia Joseph Beuys, mas este não limitava-se à linguagem oral. Não temos o objetivo de entrar profundamente nas análises de Maturana e Varella mas, a partir da determinante definição da capacidade linguística do ser humano, relacionar o conceito de comunicação destes com o de Beuys, quando eles afirmam que o conhecer acontece a partir do processo da linguagem:

(...) é dentro do linguajar mesmo que o ato de conhecer, na coordenação comportamental que é a linguagem, produz um mundo. (...) num contínuo existir nos mundos lingüísticos e semânticos que produzimos com os outros ${ }^{35}$.

Retomando o conceito de Escultura Social, verificamos que a construção do conceito está relacionada com a estética, a vida e a espiritualidade em diversos autores. Além do pedagogo e filósofo Rudolf Steiner, percebemos diálogos com os pensadores do romantismo alemão tais como Schiller, Goethe e Hegel, que foram estudados por Beuys. Por exemplo, quando Beuys responde a Bastian que sempre esteve interessado no processo artístico que o antecedeu. Sua arte está próxima dos românticos "como em Novalis, Goethe, Lorenz Ocken, Carl Gustav Crus ou Gaspar David Friedrich, Schelling, Hegel etc. Mais tarde você encontra em outras pessoas como Rudolf Steiner". Seguindo ainda o mesmo Bastian, Beuys comenta que esse seria o melhor caminho, "pois esses autores antecipam algo que nunca veio à tona" ${ }^{36}$. Na tradução que propomos realizar, todas as referências teóricas que fundamentam Joseph Beuys são importantes para entendermos sua atitude na arte. A partir dessa fala em Bastian, bem como em d'Avossa ${ }^{37}$, Adriani, Thomas e Konnertz ${ }^{38}$, pesquisamos as obras 
de alguns dos citados filósofos e escritores românticos, e encontramos concepções que acreditamos estarem em consonância com o conceito de Escultura Social de Joseph Beuys: o conceito de Espírito Absoluto em Hegel; as cartas sobre educação estética, de Schiller; a vivência e escritos como Fausto e Memórias: poesia e verdade, de Goethe; bem como as poesias de Novalis, em sua obra Pólen.

Na Escultura Social, Beuys refere-se ao princípio da linguagem e à presença do corpo como meio de comunicação. A fala, que requer pensamento e raciocínio, e o comportamento, que implicavam em atitudes e relações; ambos requerem uma estrutura cultural, filosófica, política e histórica. Em entrevista a Horsefield em 1980, Beuys expõe-se a respeito da forma que atuava nas conferências/diálogos, referindo-se que a Escultura é a melhor forma de alargar a compreensão da arte. Para ele, os processos comunicativos promovidos pela Escultura Social expressam conteúdos que vão além dos materiais, exigindo a língua, a laringe, a boca e o ar, as ondas sonoras e ouvidos de cada pessoa; estaria assim antecipando a ideia de escultura para o futuro ${ }^{39}$. Na proposta beuysiana, percebemos um modelo de interações comunicativas que os autores Maturana e Varella, compreendem como fenômenos sociais de comunicação no sentido de que:

\begin{abstract}
Não podemos compreender a comunicação como transmissão de informações, mas que cada pessoa diz o que diz e ouve o que ouve segundo sua própria determinação estrutural. (...) O fenômeno da comunicação não depende do que se fornece, e sim do que acontece com o receptor. E isso é muito diferente de "transmitir informação"
\end{abstract}

Outro aspecto relevante na relação de comunicação que verificamos entre esses autores e Joseph Beuys é sobre a conduta cultural que na obra deste, especialmente em Energy plan for a western man, propõe uma nova forma de o mundo ocidental enxergar a si mesmo. Beuys fundamenta-se nas questões culturais, econômicas, na falta de comunicação entre o mundo ocidental e oriental, encontrada principalmente nos Estados Unidos, o que justifica a apresentação dessa obra em Nova Iorque, Chicago e Minneapolis ${ }^{41}$. Em Maturana e Varella, as condutas sociais no processo de comunicação aparecem como premissas fundamentais para a organização do sistema de formação do conhecimento humano, compreendidas "precisamente a todo o conjunto de interações comunicativas de determinação ontogênica que permitem uma certa invariância na história do grupo, indo além da história particular dos indivíduos participantes”42.

\section{MAGDA SALETE VICINI}

Dimensões

comunicacionais no conceito de escultura social de Joseph Beuys como possibilidade de tradução criativa.

39. KUONI, Carin. Op. cit., p. 72.

40. MATURANA, Humberto R. \& VARELLA, Francisco G. Op. cit., p. 217.

41. TISDALL, Caroline. Op. cit., 2008, p. 8.

42. MATURANA, Humberto R. \& VARELLA, Francisco G. Op. cit., p. 225. 
Essa homogeneidade (invariância), em nosso entendimento, justi-

43. BASTIAN, Heiner \& SIMMEN, Jeannot. Op. cit., 1979, p. 92.

44. D'AVOSSA, Antonio. Op. cit., p. 14.

45. BENJAMIN, Walter apud BRANCO, Lucia Castelo. A tarefa do tradutor, de Walter Benjamin: quatro traduções para o português. Belo Horizonte: Ed. Fale, 2008, p. 25. fica a cultura comum dos grupos e sociedades - com a qual podemos nos identificar enquanto coletivo - que Beuys procura trazer à tona enquanto tradição e comunicação. Podemos verificar melhor essa análise quando Beuys é questionado sobre suas características xamânicas, em relação ao passado que ele reivindica e ao presente que ele expressa, como apresentamos em Bastian e Simmen ${ }^{43}$, como um desejo das forças perdidas que seria preciso rever no contexto vivido por Beuys.

D'Avossa acredita que a obra de Joseph Beuys tem, acima de tudo, um projeto de comunicação revelado por essa fala do artista dita em Munique, um ano antes de sua morte:

\begin{abstract}
Meu caminho passava pela palavra. Por mais que pareça estranho, não provinha do chamado talento artístico. Quando percebi que a palavra seria também uma via única, então decidi-me pela arte (...). A arte me levou ao conceito de uma escultura que começa na palavra e no pensamento. Que aprende a construir ideias com a palavra, e a transferir, para as formas, o sentir e o querer. Se o pensamento não falhar nessa tarefa, se prosseguir inabalável, aparecerão imagens que espelham o futuro. As ideias tomarão forma ${ }^{44}$.
\end{abstract}

Formada a rede de reflexões sobre Beuys, sua arte, a Escultura Social, a comunicação, passamos então a raciocinar sobre a possibilidade de traduzirmos a Escultura Social. Nesse sentido, Walter Benjamin é imprescindível no sentido de que nos faz refletir profundamente a respeito da lógica exposta no início de seu texto "A tarefa do tradutor", que foi assim traduzida: "será que uma tradução seja válida em termos dos leitores que não entendem a obra original?" ${ }^{45}$ Seria simplesmente essa a finalidade de tradução de obras, para atender a um público que não compreende a língua original da obra, ou seria outra a tarefa do tradutor? Benjamin questiona se a obra de arte é construída para o público, ou se ela é para si, como obra voltada ao espírito, à "existência e essência do humano".

Para compreender essa proposta de Benjamin, acreditamos ser necessário entender, em nossa visão, se o artista ou o poeta que se expressa por meio de uma linguagem, pretende revelar sua percepção de cultura compreendida como "formas" de comunicação e de comportamento. Essas formas se originam de particularidades de conhecimento: dos sentimentos, da visão crítica, do conhecimento técnico e científico e da vivência. Os sentimentos se constroem a partir da espiritualidade, da linguagem e 
do afeto (amor); a visão crítica, do confronto dessas diferentes concepções e percepções da arte expostas ao mundo; o conhecimento técnico e científico depende da pesquisa e do desejo; e a vivência é decorrente da gênese e apropriação de mundo.

Ao longo dos textos de Edwin Gentzler ${ }^{46}$, observamos que as teorias de tradução, desde sua origem, trazem aspectos hermenêuticos, humanistas, positivistas, estruturalistas, desconstrutivistas, históricos/culturais, sistematizantes, na busca de uma teoria científica ou uma metodologia que possa explicar como, por que e o que traduzir. Acreditamos que um dos apontamentos importantes da tradução, destacados pelo autor, são as questões levantadas por André Lefevere, que foi professor na Universidade do Texas (EUA), e Susan Bassnett ${ }^{47}$.

(...) por que certos textos são traduzidos e outros não? Qual é a intenção por trás da tradução? Como os tradutores são usados por quem tem tal intenção? Podemos prever como uma tradução poderia funcionar em determinada cultura: Algumas áreas para futuras pesquisas, segundo Bassnett e Lefevere, são o estudo de história para revitalizar o presente, o estudo de tradução pós-colonial para reavaliar modelos eurocêntricos e o estudo de diferentes espécies de críticas, antologias e obras de referência, bem como traduções, para ver como as imagens de textos são criadas e funcionam dentro de uma cultura ${ }^{48}$.

Tornou-se essencial em nosso processo criativo para a tradução aprofundarmos a relação entre nosso contexto da arte brasileira e artistas internacionais que possam ter referência na obra de Joseph Beuys. Pesquisando as obras de Ayrson Heráclito (1968) ${ }^{49}$ e analisando suas entrevistas, as críticas e ensaios sobre seu trabalho, vemos a aproximação de sua poética com a Escultura Social de Joseph Beuys. Ainda em 1995, Heráclito produziu a instalação Kiry, Bewys, Salvador, na qual utiliza charque, dendê e doze imagens do Sagrado Coração de Jesus fazendo referências ao cristianismo e ao universo religioso baiano. A cada imagem de Cristo ele dedica um aspecto da realidade contemporânea, escrevendo "O inventor do HIV", "O inventor dos Direitos Autorais", entre outras inscrições. Encontramos também em Rubens Espírito Santo (1966), artista que reside em São Paulo e coordena o Atelier do Centro, uma proposta de formação artística não acadêmica. Como artista, Espírito Santo busca em Joseph Beuys uma fonte de referências no sentido de identificação entre arte e vida. "Penso também, cada vez mais, juntar
MAGDA SALETE VICINI

Dimensões

comunicacionais no

conceito de escultura

social de Joseph Beuys

como possibilidade de

tradução criativa.

46. Diretor do Centro de Tradução e

professor adjunto de

Literatura Comparada

da Universidade de

Massachusetts Amherst.

47. Professora de Literatura Comparada da Universidade de Warwik (Inglaterra).

48. GENTZLER, Edwin. Teorias contemporâneas da tradução. São Paulo: Ed. Madras, 2009, p. 237.

49. Artista plástico e professor na Universidade Federal do Recôncavo Baiano. Ver <www2.sescsp.org. br/sesc/videobrasil/ site/pop_foto.asp> lacesso em: julho de 2011) e o site do artista sayrsonheraclito. blogspot.com> lacesso em: julho de 2011).

50. Disponível em: «www.iberecamargo.org. $\mathrm{br} /$ inc/download. asp? $i d=153 \&$ tipo= reportagem .

Acesso em: julho de 2011. 
ARS

ano 11

n. 22

51. Anselm Kiefer, painting life art. In: The Guardian online.

Disponível em: <www.guardian.co.uk/ artanddesign/2011/ mar/21/anselm-kieferpainting-life-art>. Acesso em: maio de 2011.

52. Idem.

53. Disponível em: < www. brookes.ac.uk/schools/ apm/social_sculpture/ exchangevalues/pdfs/ shelleysacks1.pdf>. Acesso em: julho de 2011.

54. PLAZA, Julio.

Tradução intersemiótica. São Paulo: Perspectiva, 2003, p. 93. as coisas, ou seja, escultura, gravura, desenho, pintura, vídeo, cinema, psicanálise, filosofia. Tornar meu trabalho cada vez mais próximo do artista alemão Joseph Beuys, cada vez mais filosófico, quase que se confundindo com a própria vida" ${ }^{50}$.

Para o crítico de arte do Jornal The Guardian, Jonathan Jones ${ }^{51}$, Joseph Beuys mostrou que a arte, a partir do mito e da memória, pode encontrar formas de renovar o mundo, e que deixou o legado em Anselm Kiefer (1945) e Gerhard Richter (1932), sendo que este último renegou este mesmo legado. Anselm Kiefer estudou na mesma academia de Düsseldorf que o mestre, quando Beuys lá era professor. Declara que nunca assistiu a suas aulas, mas, por muitas vezes, mostrou seu trabalho ao professor Beuys. Kiefer, segundo Jones, lembra que ele reagia diferentemente dos outros professores, dizendo “'vá em frente pois é uma boa ação', e para ele, ação era arte" ${ }_{52}$. Na Universidade de Oxford, a diretora da Unidade de Pesquisa em Escultura Social, a artista Shelley Sacks (1959), desenvolve um trabalho interdisciplinar na arte. Sacks estudou com Beuys na década de 1970 e atuou em diversas Esculturas Sociais até 1986. Seu trabalho interdisciplinar está preocupado com o diálogo, a agência criativa, a relação entre estética e ética, facilitando a nova visão, e o papel da imaginação no processo social de transformação. Seu trabalho varia entre ações performativas, mapeamento de processos, intervenções e processos de diálogo, “para facilitar 'espaços para a nova visão' no nosso trabalho em direção a um mundo ecologicamente sustentável”. Ela descreve seus projetos de esculturas sociais que envolvem "quadros flexíveis" e "kits" como "instrumentos de consciência" e não "objetos de atenção" ${ }^{53}$. O conhecimento que obtivemos sobre esses artistas fez com que acontecesse a aproximação entre fatos, textos, críticas e a reflexão sobre a Escultura Social, para afirmarmos nossa proposta de tradução durante a pesquisa.

Ao compreendermos a tradução e suas possibilidades de transformação, e ao chegarmos a uma clareza sobre o conceito de Escultura Social em Joseph Beuys, decidimos que faremos a produção digital como obra de tradução simbólica.

Este tipo de tradução opera pela contiguidade instituída, o que é feito através de metáforas, símbolos ou outros signos de caráter convencional. Ao tornar dominante a referência simbólica, eludem-se os caracteres do Objeto Imediato, essência do original. A tradução simbólica define "a priori" significados lógicos, mais abstratos e intelectuais do que sensíveis ${ }^{54}$. 
Conforme Benjamin, uma das possibilidades para descobrir a traduzibilidade de uma obra é se a natureza da obra permite uma tradução ${ }^{55}$. Estamos verificando e tentando comprovar que o conceito de Escultura Social na obra de Beuys está inserido em sua vasta produção, com o objetivo de chegar o mais longe possível, de várias formas e meios, a ilimitado número de pessoas. Isso revela o desejo de comunicação na proposta beuysiana, mas que não pode ser compreendido como qualquer forma de comunicação quando se tem em conta os conteúdos que desenvolvemos como prerrogativa para defendermos nossa pesquisa. Beuys pretendia unir a racionalidade científica com a intuição que provém da cultura, para uma possível transformação humana e social. Beuys apropria-se do conhecimento vivido e teórico para construir o conceito ampliado de arte: Escultura Social como experiência estética e de vida. Estética porque inserida dentro da arte, e porque pretende provocar, em nossa concepção, o transcendental da sensibilidade, que seria uma antiestética em Beuys.

Com o propósito de traduzirmos a Escultura Social da obra de Joseph Beuys, integramos todas as informações de vida, obra e contexto para compreendermos o "modo-de-querer-dizer" de sua arte, apontando e refletindo as particularidades na instauração desse conceito ${ }^{56}$. Buscamos assim compreender que relações esta pesquisadora tem com o artista Beuys, o que Benjamin denomina "relação vital" 57 e o tradutor de Benjamin, Barck, nomeia por "vínculo de vida" ${ }^{58}$. Ao longo de seu artigo, em muitos parágrafos, Benjamin ${ }^{59}$ deixa claro que traduzir não significa comunicar simplesmente, mas sim ir além de qualquer comunicação, em qualquer linguagem ou imagem, pois existe algo superior ao significado que as línguas literalmente dizem. Nelas, encontramos o "Simbolizante ou um Simbolizado”, algo que não é comunicável, é próprio das línguas, e que ele chama de "Língua pura do original", o que precisa ganhar significado também na tradução. Para Benjamin, atingir a Língua pura é o maior poder do tradutor, e "é essa a tarefa do tradutor" ${ }^{60}$. Vemos aqui a relação que o tradutor deveria manter entre o original e a tradução, no sentido de ter liberdade e fidelidade para a construção de uma tradução em outra obra, o que percebemos, não difere entre a literatura e as artes visuais, buscando sempre a essência da obra, voltando à ideia de Benjamin de que a justificativa para a criação de uma obra é a "vivência e a essência do humano"61.

Sobre essa complexidade que permeia a tradução, Georg Steiner declara que, da mesma forma, nosso discurso interior tem diferenças quanto ao que falamos para nós mesmos e o que falamos para os outros ${ }^{62}$.

\section{MAGDA SALETE VICINI}

Dimensões

comunicacionais no

conceito de escultura

social de Joseph Beuys

como possibilidade de

tradução criativa.

55. BENJAMIN, Walter apud BRANCO, Lucia Castelo. Op. cit., p. 26.

56. Idem, p. 28 a 30.

57. Idem, p. 27.

58. apud BRANCO, Lucia Castelo, Op. cit., p. 53.

59. Idem. p. 39-40.

60. Idem, p. 40.

61. Idem, p. 25.

62. Cf. STEINER, Georg. Depois de babel: questões de linguagem e tradução. Curitiba: Editora UFBR, 2005, p. 45. Georg Steiner (1929) é professor de Literatura Comparada da Universidade de Oxford. 
ARS

ano 11

n. 22

63. Cf. Idem, p. 53-54.

64. GADAMER, Hans-Georg. Verdade e método - traços fundamentais de uma hermenêutica filosófica. Petrópolis: Ed. Vozes, 1997, p. 562.

65. CAMPOS, Haroldo de. Metalinguagem e outras metas. São Paulo: Ed. Perspectiva, 2006, p. 35.

66. Professora e pesquisadora do Centro de Estudos de Crítica Genética da PUC-SP.

67. SALLES, Cecília Almeida. Gesto inacabado: processo de criação artística. São Paulo: Annablume/ Fapesp, 1998, p. 38.
Mesmo quando lemos um produto literário em nossa própria língua, que Steiner chama "tradutor/intérprete interno", realizamos uma interpretação que envolve conhecimentos, familiaridade e intuições recriativas. O mesmo acontece com o "tradutor /intérprete 'externo" em relação à linguagem estrangeira à de seu país ${ }^{63}$. Questionamo-nos, nesse sentido, o que seria a interpretação/tradução do conceito de Escultura Social em nosso contexto? Também na compreensão de Hans-Georg Gadamer nos perguntamos se seria possível desenvolver "uma reconstituição do texto guiada pela compreensão do que se diz nele. Não há dúvida de que se trata de uma interpretação e não de uma simples co-realização" ${ }^{64}$. Nesse sentido, a obra beuysiana pode nos oferecer um amplo campo de ideias, a partir do que estamos analisando, comparável a toda grande escritura, como, por exemplo, o Fausto de Goethe, do qual Haroldo de Campos transcria a poesia fundamentando-a, principalmente, como obra voltada à paródia, relacionando alguns tradutores de Fausto até chegar ao seu objetivo de tradução como transcriação:

\begin{abstract}
Numa tradução dessa natureza, não se traduz apenas o significado, traduz-se o próprio signo, ou seja, sua fisicalidade, sua materialidade mesma (propriedades sonoras, de imagética visual, enfim tudo aquilo que forma) (...). O significado, o parâmetro semântico, será apenas e tão-somente a baliza demarcatória do lugar da empresa recriadora. Está-se pois no avesso da chamada tradução literal ${ }^{65}$.
\end{abstract}

Considerando essas visões sobre a tradução, pretendemos conduzir nossa tradução do conceito de Escultura Social à consideração dessas perspectivas como fundamento para nosso processo criativo, que, conforme Cecília Salles ${ }^{66}$ :

O tempo e o espaço do objeto em criação são únicos e singulares e surgem de características que o artista vai lhes oferecendo, porém se alimentam do tempo e espaço que envolvem sua produção. [Mikhail] Bakhtin afirma que "as grandes descobertas do gênio humano só são possíveis em condições determinadas de épocas determinadas, mas elas nunca se extinguem nem se desvalorizam juntamente com as épocas que as geraram". É importante ressaltar que a mera constatação da influência do contexto não nos leva ao processo propriamente dito. $\mathrm{O}$ que se busca é como esse tempo e espaço, em que o artista está imerso, passam a pertencer à obra. Como a realidade externa penetra o mundo que a obra apresenta ${ }^{67}$. 
Dentre os sistemas de tradução citados por Georg Steiner, encontramos a abordagem do linguista Roman Jakobson (1896-1982), que se fundamenta na teoria semiótica de Peirce, presente na proposta de "tradução intersemiótica” de Julio Plaza ${ }^{68}$. A tradução, para Jakobson, "é um discurso citado; o tradutor recodifica e transmite uma mensagem recebida de outra fonte. Assim, a tradução envolve duas mensagens equivalentes em dois códigos diferentes"; poesias, pinturas, música, cinema, fotografias e textos são elementos de tradução ${ }^{69}$. Para Georg Steiner, essa prática tradutiva "Ao usar o termo neutro 'envolve', Jakobson passa ao largo do dilema hermenêutico fundamental, que é saber se faz sentido falar de mensagens como sendo 'equivalentes' quando os códigos são diferentes"70, uma vez que a tradução não é só o nível semântico; ele a vê como uma "teoria da tradução", um "modelo histórico-psicológico, parte dedutivo, parte intuitivo, das operações de linguagem em si. Uma compreensão da compreensão, uma hermenêutica, inclui ambos, e a tradução não se limita à tradução verbal em verbal"71.

O fato que nos chama a atenção para o fenômeno ou metodologia da tradução é a universalidade que ela significa no sentido de vivermos em constante tradução de mundo, de ideias, de obras, palavras, imagens, sons e pensamentos que constituem nossa vivência. E, para nossa pesquisa, a proposta é traduzir o conceito de Escultura Social em Joseph Beuys - um sistema comunicacional e da vida deste artista -, que está densamente repleta da substância ${ }^{72}$ cultural que pretendemos promover e transformar em outra obra para nossa cultura vivida.

Ao falarmos de obras comunicacionais, como as de Joseph Beuys, perguntamo-nos por que traduzir o conceito de Escultura Social desse artista? Não pretendemos traduzir o conceito de Escultura Social para "explicá-lo" ou "significá-lo", pois o conceito, assim como as obras, foram criadas para "serem" obras, da mesma forma que tantas outras obras foram produzidas por muitos artistas na história da arte. Algumas perguntas nos indagam a respeito da nossa proposta de tradução: qual o direcionamento midiático que melhor contribuiria para traduzir o potencial hipermidiático da arte de Joseph Beuys? O questionamento sobre as diferenças acerca do conceito de Escultura Social identificadas entre os autores que citamos no primeiro capítulo - Tisdall, Borer e Bunge -, poderão nos levar a fundamentos que possam proporcionar uma aproximação de definição deste conceito? E, finalmente, nossa identificação com a obra de Joseph Beuys, como artista e pesquisadora, poderá construir uma produção

\section{MAGDA SALETE VICINI}

Dimensões

comunicacionais no

conceito de escultura

social de Joseph Beuys

como possibilidade de

tradução criativa.

68. Cf. PLAZA, Julio. Op. cit.

69. Cf. STEINER, Georg. Op. cit., p. 282.

70. Idem, p. 283.

71. STEINER, Georg. Op. cit., p. 437.

72. “0 espírito é a substância e a essência universal, igual a si mesma e permanente: 0 inabalável e irredutível fundamento e ponto de partida do agir de todos, seu fim e sua meta, como [também] o Em-si pensado de toda a consciência-de-si. Essa substância é igualmente a obra universal que, mediante o agir de todos e de cada um, se engendra como sua unidade e igualdade, pois ela é o ser-para-si, o Si, o agir". HEGEL, Georg Wilhelm Friedrich. A fenomenologia do espírito. São Paulo: Vozes, 2008, p. 305. 
ARS artística que possa sustentar os fundamentos que estamos descobrindo serem essenciais no conceito de Escultura Social?

73. Filosoficamente falando, o Outro que está em nós e o Outro diferente de nós: "Para a consciência-de-si há uma outra consciênciade-si [ou seja]: ela veio para fora de si. Isso tem dupla significação: primeiro, ela se perdeu a si mesma, pois se acha numa outra essência. Segundo, com isso ela suprassumiu o Outro, pois não é o Outro como essência, mas é a si mesma que vê no Outro". Idem, p. 143).

74. Como artista plástica, saliento a importância das Bienais de $1985 \mathrm{com}$ a curadoria de Sheila Leirner, e a Bienal de 2006, com a curadoria de Lizete Lagnado para o desenvolvimento de minha percepção para a arte.

75. Imagens de meus trabalhos artísticos produzidos desde 1986 podem ser visualizados no site <www. magdavicini.com.br〉.

76. Projeto de entrevistas e conversas com mulheres de um bairro periférico da cidade de Xanxerê (SC).
Nossa construção da compreensão de Escultura Social em Joseph Beuys originou uma rede de referências que nos forneceram substratos para chegar à linguagem ou ao meio que poderá abrigar nossa tradução desse conceito: a produção de um videoaudio. $\mathrm{O}$ símbolo que acreditamos traduzir como Objeto Imediato do conceito de Escultura Social é a fala, como definiu Borer. Mas para este autor, a compreensão da escultura de Joseph Beuy se dá pela fala do próprio artista. Entendemos que este Objeto Imediato "fala", para nossa tradução, deve ter como foco principal, a fala do Outro $^{73}$. Não daremos destaque à nossa fala como pesquisadora e artista que propõe a produção da obra, mas dos indivíduos de nosso entorno, partindo dos pressupostos desenvolvidos no processo criativo para esta tradução. Já em Beuys, o foco estaria na fala que se origina do próprio artista, como protagonista de todas as suas produções enquanto Escultura Social. Termos chegado a essa resposta nos leva a questionar nossa própria vivência em nosso entorno.

Nossa preocupação como artista plástica ${ }^{74}$ sempre esteve atrelada às condições sociais brasileiras, desde quando iniciamos o trabalho na arte. Nas pinturas, desenhos, instalações e performances que já produzimos, a preocupação com a condição da mulher, dos índios, dos migrantes rurais, da educação, da condição política e social na atualidade, foram temáticas que nos impulsionaram a criar. Ou seja, levantando aspectos sociais e da arte como expressão de vida, situamos o que produzimos como arte engajada com nosso contexto regional: pinturas em tela, como as da série Resignação política, social e sexual (1986), expressando a resignação feminina em técnica de tinta acrílica; a série de desenhos Fragmentos indígenas (1988), em grafite, carvão, pastel e aquarela, além das pinturas em tinta acrílica e óleo sobre tela, também da mesma série; pinturas da série e performance Cortes (1993-1995); pinturas da série o universo é tudo, inclusive você (1998); pinturas da série Encontro com a Luz (2000); pinturas, vídeo e instalação Rituais (2005), enfocando os rituais católicos e kaingangues ${ }^{75}$. $\mathrm{O}$ encontro com a obra de Joseph Beuys nos trouxe à memória todos esses aspectos sociais vividos em nosso entorno, acrescentando as experiências profissionais diárias, como no projeto sobre cultura e cidadania que desenvolvemos na Prefeitura Municipal de Xanxerê entre 2009 e $2011^{76}$. Esse olhar e atuar é o que acreditamos ser o fundamento para os próximos passos e continuação dessa política de vida e de arte, 
principalmente para esta tradução. Como também nossa atuação atual (2013) com mães e crianças em vulnerabilidade social que frequentam a Pastoral da Criança nesta mesma cidade de Xanxerê.

Notamos que esses aspectos sociais permanecem quase ocultos, sem expressividade frente ao cotidiano da maioria das pessoas. As pessoas que vivem em situação de vulnerabilidade social sempre foram percebidas pelos nossos olhos e pela nossa mente de artista plástica, o que acreditamos poder ter relação com o projeto de Joseph Beuys. Propomos iniciar as ações para a tradução do conceito de Escultura Social de Joseph Beuys com entrevistas a grupos de crianças e adultos em situação de vulnerabilidade social. Joseph Beuys apresentava sua arte a partir de sua fala com o público; em nossa tradução, propomos a fala do Outro como proposta de arte.

O primeiro grupo de pessoas que nos chama a atenção é o das crianças de menor idade, que permanecem nos abrigos sociais, à espera de adoção ou à espera de que sejam solucionados seus problemas familiares, para, então, voltarem a suas casas. No roteiro que elaboramos, elas falarão sobre seus desejos e suas vidas: como elas enxergam o mundo, o que elas pensam sobre o abrigo, a casa, o que elas sonham sobre suas vidas, brinquedos, escola, seu viver. Outro grupo de pessoas a que propomos a gravação de entrevista é o dos os índios Kaingangues, que vivem na região oeste de Santa Catarina, e que passamos a compreender melhor a partir das conversas com o antropólogo canadense, Robert Crépeau, da Universidade de Montreal, pesquisador da área indígena denominada Xapecó (SC) desde a década de 1990. Anteriormente ao encontro com Crépeau, realizamos visitas às áreas indígenas regionais para realizar desenhos e pinturas, tendo a vivência deles como temática para exposições realizadas entre 1980 e 1990. Buscamos, para a captação de áudio, realizar o diálogo com os índios que circulam em nossa cidade diariamente, vendendo seus produtos. O terceiro grupo de pessoas que faz parte do processo de nossa tradução participou de um projeto sócio-cultural que foi realizado na Prefeitura Municipal de Xanxerê, na qual eu ocupava o cargo de diretora de cultura: Projeto Cultura como Fundamento para a Cidadania. O objetivo desse trabalho era provocar as 32 famílias que foram convidadas a participarem do projeto a pensarem sobre sua cultura, o que envolve: a origem, a forma de trabalho, a lembrança da infância, da escola e da família; as relações que elas têm com o bairro, a cidade e sua própria casa. Segundo os estudos da UNESCO: 
Vale notar que a vulnerabilidade assim compreendida traduz a situação em que o conjunto de características, recursos e habilidades inerentes a um dado grupo social se revelam insuficientes, inadequados ou difíceis para lidar com o sistema de oportunidades oferecido pela sociedade, de forma a ascender a maiores níveis de bem-estar ou diminuir probabilidades de deteriorização das condições de vida de determinados atores sociais. Esta situação pode se manifestar, em um plano estrutural, por uma elevada propensão à mobilidade descendente desses atores e, no plano mais subjetivo, pelo desenvolvimento dos sentimentos de incerteza e insegurança entre eles ${ }^{77}$.

77. ABRAMOVAY, Miriam; et al. Juventude, Violência e Vulnerabilidade Social na América Latina: Desafios para Políticas Públicas Brasília: UNESCO/BID, 2002. Disponível em: <http://unesdoc.unesco. org/images/0012/001 271/127138 por.pdf>. Acesso em: junho de 2011.

78. FLUSSER, Vilém. 0 universo das imagens técnicas: elogio da superficialidade. São Paulo: Annablume, 2008, p. 71.
Dando continuidade à definição de nosso contexto e meio para a tradução, fomos percebendo que nosso objetivo de produção digital a partir da concepção da Escultura Social em Joseph Beuys se aproxima da videoarte. A videoarte, como proposta engajada, acreditamos poder se aproximar de um aspecto que Flusser chama de "novos revolucionários são "imaginadores" profissionais engajados, que procuram "injetar valores, "politizar" as imagens, a fim de criar sociedade digna de homens". E ainda, Flusser reflete que

Tal reformulação revolucionária da sociedade informática, na qual as imagens deixariam de ser imperativas e passariam a ser dialógicas, seria ainda sociedade "informática", mas com um significado novo para o termo. As imagens passariam a merecer no nome media, nome a que hoje injustamente se atribuem, e o propósito da sociedade seria o de criar informações em colaboração de todos com todos. "Cultura democrática" em vez de "cultura de massa" ${ }^{\text {. }}$.

Flusser, aqui, critica a imagem como entorpecimento, como busca de eterna felicidade e divertimento, ocultando a essência humana, que poderia ser compartilhada numa nova proposta de imagem. Essa cultura democrática pertence também a nossa concepção de Escultura Social, acessível, reveladora do silêncio das forças visíveis e invisíveis da sociedade em vulnerabilidade de direitos sociais. Nossa proposta é aproximarmos a tradução de Escultura Social da arte engajada, a qual me filio como artista plástica. Acreditamos que a arte procura refletir sempre o momento vivido, como uma espécie de "luneta da subjetividade", ou ainda, como um "sensor do inconsciente coletivo". Pensamos que a arte torna diferenciado o artista, o escritor, o fotógrafo, o músico, o coreógrafo, o diretor de cinema, o poeta, a partir do "modo-de-querer-dizer" de Benjamin, ou da "poética do espaço", como nos faz refletir Gaston Bachelard e, em algum 
sentido, também Hegel ${ }^{79}$, que a arte "sirva para acordar em nós o sentiMAGDA SALETE VICINI mento e a consciência de algo mais elevado".

A escuta do Outro, que realizamos durante as gravações do videoaudio FaladoOutro/EscutaImagem, nos conduziu a pensamentos sobre a forma de expressão que se reflete na forma de vida que as pessoas participantes utilizaram. A partitura ou roteiro do videoaudio, aos poucos nos levou a compreender a pesquisa da linguagem em George Steiner ${ }^{80}$, especialmente quando esse autor apresenta sua preocupação quanto à diversidade de línguas existente no mundo: o que as levaria à extinção, à não identificação, ou autoexclusão - por que temos tantas diferenças linguísticas, mesmo se vivermos em um mesmo clima, território, etnia e economia?

Com o simples acréscimo de neologismos e empréstimos, qualquer língua pode ser usada bastante eficazmente em qualquer lugar. A sintaxe do esquimó é adequada ao Saara. Longe de ser econômica e demonstravelmente vantajosa, a imensa quantidade e a variedade de línguas, aliadas ao fato da mútua incompreensão, constituem um poderoso obstáculo ao progresso material e social da espécie. No entanto, os muitos modos como elas têm impedido o progresso humano são claramente visíveis. (...) Numerosas culturas e comunidades passaram pela história como ausentes linguísticos. E isso não porque sua língua era, em qualquer sentido, inadequada, mas porque ela impediu a comunicação com as principais correntes das forças intelectuais e políticas. Inúmeras sociedades tribais feneceram, isoladas por barreiras lingüísticas até mesmo de seus vizinhos mais próximos ${ }^{81}$.

Pensamos que a busca de Joseph Beuys ao dizer que "o homem em geral é capaz de criar substâncias por si próprio como princípio criativo"82 faz do homem a potência essencial de comunicação para qualquer busca de transformação, indo além do que ele conhece como realidade visível, estabelecida como realidade. Acreditamos que, em Joseph Beuys, sua arte e sua vida permanecem abertas ao mundo como toda e qualquer obra que consegue comunicar o indizível que manifesta o óbvio, após exposto ao Outro: FALADOOUTRO/ESCUTAIMAGEM.

82. BASTIAN, Heiner \& SIMMEN, Jeannot. Op. cit., 1979, p. 29.
79. Apud BASTIAN, Heiner \& SIMMEN, Jeannot. Op. cit., 1979, p. 98.

80. Cf. Op. cit., p. 77 a 82.
81. Idem, p. 83 
ARS Bibliografia complementar

ano 11

n. 22 ARCHER, Michael. Arte contemporânea: uma história concisa. São Paulo: Ed. Martins Fontes, 2008.

BACHELARD, Gaston. A poética do espaço. São Paulo: Ed. Martins Fontes, 2008.

CAMPOS, Haroldo de. Deus e o diabo no Fausto de Goethe. São Paulo: Ed. Perspectiva, 2005. GOETHE, Johan Wolfgang Von. Memórias: poesia e verdade, vols. I e II.. Brasília: Editora Universidade de Brasília/HUCITEC, 1986.

. Os sofrimentos do jovem Werther. São Paulo: W.M. Jackson Inc. Editores, 1963.

HEGEL, Georg Wilhelm Friedrich. Curso de estética: o belo na arte. São Paulo: Martins

Fontes, 1996.

LAUF, Cornelia. Joseph Beuys: the pedagogue as persona. Tese de Doutorado. Nova Iorque: Columbia University, 1992.

NOVALIS (Friedrich von Hardenberg). Pólen: fragmentos, diálogos e monólogo. São

Paulo: Iluminuras, 1988.

RUSH, Michael. Novas mídias na arte contemporânea. São Paulo: Martins Fontes, 2006. SCHILLER, Friedrich. Sobre a educação estética do ser humano numa série de cartas e outros textos. Lisboa: Casa da Moeda, 1994.

WOOD, Paul. Arte Conceitual. Movimentos da arte moderna. São Paulo: Cosac \& Naify, 2003.

\section{Material virtual}

Blog do Atelier do Centro. Disponível em: <atelierdocentrores.wordpress.com/rubens-espirito-santo/teoria-da-arte/>. Acesso em: julho de 2011.

Exchange values (obra de Shelley Sacks). Disponível em: 〈www.exchange-values.org〉. Acesso em: julho de 2011.

Relato de Livia Benedetti sobre palestra de Antonio D’Avossa na exposição A revolução somos nós: Joseph Beuys. Disponível em: 〈www.forumpermanente.org/.event_pres/ encontros/encontro-com-antonio-d-avossa/relatos/beuys-e-a-escultura-social〉. Acesso em: setembro de 2010.

Site da artista Susan Hiller. Disponível em: «www.susanhiller.org/Info/artworks/artworks-lastsilentmovie.html». Acesso em junho de 2011.

Artigo recebido em 21 de setembro de 2013 e aprovado em 18 novembro de 2013.
Magda Salete Vicini é doutora em Comunicação e Semiótica pela PUC-SP, mestre em Educação, Arte e Cultura pela Universidade Mackenzie (SP) e graduada em Artes Plásticas pela UPF (RS). Professora da UNOESC - Universidade do Oeste de Santa Catarina, Campus de Xanxerê (SC). 